\title{
CHRONOLOGY OF SOIL EVOLUTION AND CLIMATIC CHANGES IN THE DRY STEPPE ZONE OF THE NORTHERN CAUCASUS, RUSSIA, DURING THE 3RD MILLENNIUM BC
}

\author{
A L Alexandrovskiy ${ }^{1} \cdot \mathrm{J}_{\text {van der Plicht }}^{2} \bullet \mathrm{A} \mathrm{B} \mathrm{Belinskiy}^{3} \bullet \mathrm{O}^{\mathrm{S}} \mathrm{Khokhlova}^{4}$ \\ ABSTRACT. Chrono-sequences of paleosols buried under different mounds of the large Ipatovo Kurgan, constructed dur- \\ ing the Bronze Age, have been studied to reconstruct climatic changes in the dry steppe zone of the Northern Caucasus, \\ Russia. Abrupt climatic and environmental changes in the third millennium BC have been reconstructed, using morpho- \\ logical and analytical data of the soil. Based on accelerator mass spectrometry (AMS) dates of small charcoal fragments \\ from the soil chrono-sequence, we concluded that two upper paleosols (with the clearest evidence of arid pedogenesis) \\ developed between about 2600-2450 BC.
}

\section{INTRODUCTION}

Abrupt climatic and environmental changes in arid and semi-arid regions of Eurasia during the third millennium BC are evident from several studies. These include both the investigation of archaeological monuments (Weiss et al. 1993; Dalfes et al. 1997; Gerasimenko 1997), and the study of paleosols buried under Kurgans (i.e. burial mounds) of the Bronze Age (Fedoroff et al. 1997). These paleosols developed during a long period, and only a short time before their burial underwent arid pedogenesis (Demkin 1997).

The largest Kurgans with several mounds were constructed with long intervals of interruptions, during which soils could develop. Until now there was no study of such soils because excavations of large Kurgans with a detailed study of their stratigraphy are rare.

The large Ipatovo Kurgan contains five soils, which developed during interruptions in construction of this particular Kurgan. Here we present accelerator mass spectrometry (AMS) dates of soils and mounds for the large Ipatovo Kurgan, which enables us to understand the detailed chronology of climatic changes during the third millennium BC for the dry steppe zone of the Northern Caucasus.

\section{MATERIALS AND METHODS}

The large Ipatovo Kurgan is located at the northern periphery of the Stavropol upland on a high terrace of the Kalaus River (Figure 1). The height of the Kurgan is $6.5 \mathrm{~m}$, and its construction history is rather complex. The mounds of the Kurgan were constructed during the Bronze Age, with long intervals of interruptions, in which the soils developed. A photo of the large Ipatovo Kurgan after two years of excavation is shown in Figure 2a. The large hole contained a Scythian grave (no. 14, second and third century BC), which had been excavated earlier. This grave was rich and contained gold and silver finds, among which was a bronze sword in a golden sheath. There are more than 40 graves of Early and Middle Bronze Age found in the Kurgan. The formation of all Kurgan mounds took 1500 years, during the fourth and third millennium BC. During the Scythian epoch (three large graves) and Nogay epoch (ca. 150 graves) the mounds did not grow larger.

\footnotetext{
${ }^{1}$ Institute of Geography, Russian Academy of Sciences, Moscow, Russia

${ }^{2}$ Corresponding author: Center for Isotope Research, Groningen, the Netherlands. Email: plicht@phys.rug.nl.

${ }^{3}$ State Department "Nasledie", Stavropol, Russia

${ }^{4}$ Institute of Physical, Chemical and Biological Problems of Soil Science, Russian Academy of Sciences, Pushchino, Moscow region, Russia
}

(C) 2001 by the Arizona Board of Regents on behalf of the University of Arizona RADIOCARBON, Vol 43, Nr 2B, 2001, p 629-635

Proceedings of the 17 th International ${ }^{14} \mathrm{C}$ Conference, edited by I Carmi and E Boaretto 


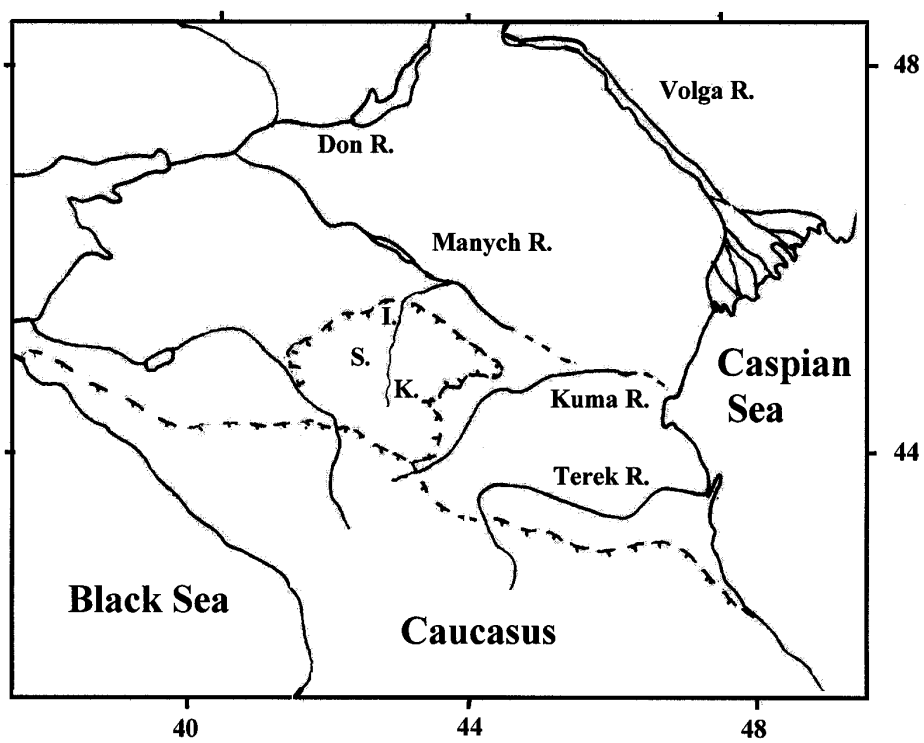

Figure 1 Location of the large Ipatovo Kurgan (I.) near Stavropol (S.) and the Kalaus River (K.) at the Stavropol upland, Russia.

In the Ipatovo Kurgan, five paleosols were found above the mounds of different ages. These paleosols have been observed not only on the top of different mounds, but also on their slopes and in colluvial deposits and ditches around the Kurgan. They have been classified as weakly developed soils (Russian soil classification 1997) or Entisols (WRB 1994). Altogether these soils (numbered 1b-4 in Figure 2b) form a vertical sequence. In the foundation of the Kurgan, a well-developed paleosol has been observed. At the central part of the Kurgan, this paleosol (no. 0, part A, Figure 2b) was buried earlier than at its periphery. For this paleosol, a horizontal sequence has been found: paleosols buried under the first, fourth (no. 0, part B, Figure 2b) and fifth mounds (no. 0, part C, Figure 2b) of the Kurgan and modern surface soil named background soil (no. 0, part D, Figure 2). These soils were classified as Solonetz and Light Kastanozem soils with some Solonetzic features (Russian soil classification 1997) or Solonetz and Luvic Kastanozem in the WRB (1994).

The age of paleosols in the vertical sequence has been determined using radiocarbon dating by AMS. The degree of morphological development of each paleosol helped to estimate the duration of its formation period. The paleosol age in the horizontal sequence has been determined using the stratigraphic correlation with soils of the vertical sequence.

The main material for ${ }^{14} \mathrm{C}$ dating was charcoal from the paleosols, consisting of fragments of twigs and burned grass. In addition, charcoal and bones found in holes made by small mammals in the first mound of the Kurgan were dated. All ${ }^{14} \mathrm{C}$ measurements were made at the Groningen AMS facility (van der Plicht et al. 2000). The ${ }^{14} \mathrm{C}$ dates obtained were calibrated using the program CAL25 (van der Plicht 1993), updated with the latest INTCAL98 calibration data (Stuiver et al. 1998).

Climatic changes could be reconstructed by comparing background soils and paleosols buried at different times, showing clear differences. These differences are due to fluctuations in humidity (Ivanov and Alexandrovskiy 1987). In paleosols of the horizontal sequence of the Ipatovo Kurgan, climatic fluctuations are determined by the depth of the gypsum; in those of the vertical sequence by the intensity of humus and carbonate accumulations and the occurrence of desiccation cracks. 


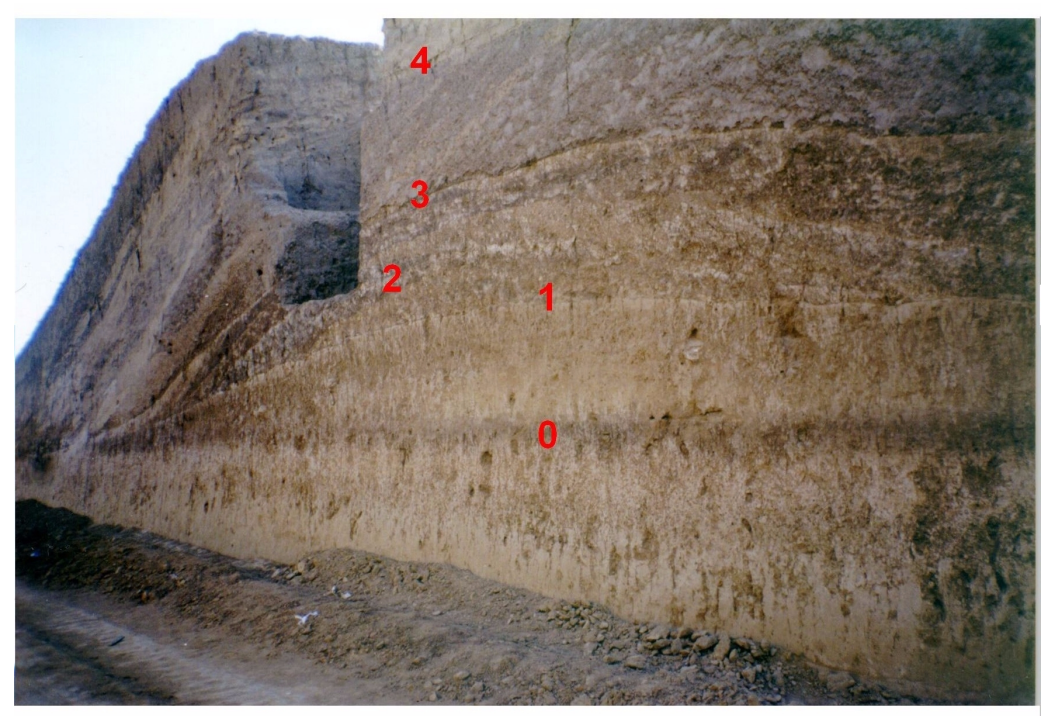

Figure 2a Photo of the large Ipatovo Kurgan, with paleosols 0-4 indicated

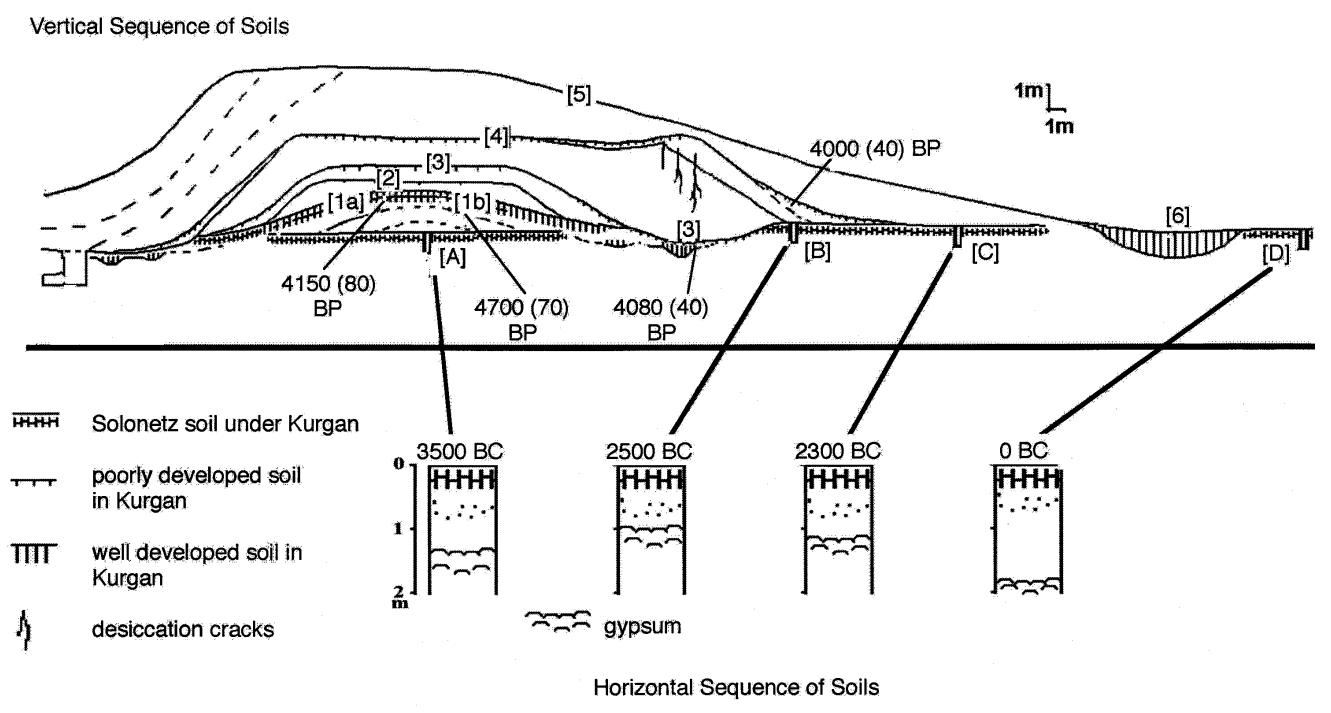

Figure $2 \mathrm{~b}$ Schematic cross-section of the large Ipatovo Kurgan.

Vertical sequence of soils: [0] — mature Solonetz soil buried under the Kurgan, [1a] and [1b] — weakly developed soils inside the Kurgan on the first mound, [2] — weakly developed soil on the second mound, [3] — weakly developed paleosol 3 with signs of the second arid stage of pedogenesis, [4] — weakly developed paleosol 4 with signs of the first arid stage of pedogenesis, [5] - modern soil, [6] — ditch. Horizontal sequence of soils (i.e. parts of the same soil buried under the mounds of different age): [A] — paleosol under the first Kurgan mound, [B] — paleosol under the fourth mound, $[\mathrm{C}]$ — paleosol under the fifth mound, $[\mathrm{D}]$ background soil. 


\section{RESULTS}

\section{Stratigraphy of the Ipatovo Kurgan and Age of the Soils}

The large Ipatovo Kurgan was constructed during the Early-Middle Bronze Age. Mound 1, in the lower central part of the Kurgan, includes six graves of the Early Bronze Age (Maikop and Yama archaeological cultures), and was constructed with two long interruptions (soils 1a and 1b, see Figure $2 \mathrm{~b}$ ). Soils developed on the second, third and fourth mounds also. The fifth mound (top of the Kurgan) contains more than 20 graves (Katakomba archaeological culture), but the soil on this mound has been destroyed long before the excavation took place.

Soils of the vertical sequence, developed during interruptions in the construction of the Kurgan, show considerable differences. Their age or the duration of each soil formation can be estimated as explained below, using the degree of morphological development of their profiles (see also Figure $2 b)$.

Paleosol 1 developed on the first Kurgan mound has been classified as Light Kastanozem (Russian soil classification 1997). Its profile was thick but well developed with an abundance of crotovinas. The uppermost gray A horizon had a thickness varying from 5 to $10 \mathrm{~cm}$, then $\mathrm{Ak}-10 \mathrm{~cm}$ and $\mathrm{Bk}-$ $50 \mathrm{~cm}$. At the central part of the Kurgan, we divided the paleosol 1 into two sections: 1a and 1b. The total time span of the first mound and the paleosols $1 \mathrm{a}$ and $1 \mathrm{~b}$ development was 500-800 yr.

Paleosol 2 on top of the second mound of the Kurgan was the least developed soil; the estimated duration of its formation was only 20-30 yr. Its morphological development was visible from the change of initial texture of spotty and clumpy fragments of the mound and from humus accumulation and carbonate leaching in the uppermost layer of the second mound (horizon A of paleosol 2). This gray A horizon was $2 \mathrm{~cm}$ thick; then there was a $\mathrm{C}$ horizon, consisting of different fragments from the second mound.

Paleosol 3 on top of the third mound of the Kurgan was weakly developed. There was a light gray calcareous Ak horizon with a thickness of $5 \mathrm{~cm}$ and a $\mathrm{C}$ horizon consisting of a mixture of different layers from the third mound in its profile. The same light gray Ak horizon was observed in the ditch, below which a thick dark gray humic A horizon without carbonates. The Ak horizon is evidence for an arid pedogenesis (the second stage of paleosol 3 formation), and the A horizon for a humid pedogenesis (the first stage of paleosol 3 formation). On the top of the third mound and on its slopes, the paleosol of the first arid stage was thin. It was completely transformed during the second humid stage of pedogenesis. The time span of the development of paleosol 3 was about $100 \mathrm{yr}$.

Paleosol 4 on top of the fourth mound of the Kurgan was also weakly developed. There was a gray, weakly calcareous Ak horizon with a thickness of $5 \mathrm{~cm}$ and a light-yellow loam, strongly calcareous Bk horizon with a thickness of $10 \mathrm{~cm}$ in its soil profile. This profile shows clear evidence for humus accumulation and carbonate leaching, and developed during the second humid stage of paleosol 4 formation. During the first arid stage of its pedogenesis, the thick (up to $3 \mathrm{~m}$ ) and branching desiccation cracks were formed on the southern slope of the fourth mound of the Kurgan. There were no such cracks in other paleosols and mounds of the Kurgan. The duration of the formation of paleosol 4 was also about $100 \mathrm{yr}$.

The results of the ${ }^{14} \mathrm{C}$ measurements are shown in Table 1 . The ${ }^{14} \mathrm{C}$ age of the paleosol 4 is the most representative. After calibration and using the estimated duration of development of paleosol 4, we conclude that the time of its formation is in the range 2550-2450 BC. 
Table 1 Radiocarbon dates for the large Ipatovo Kurgan. Calibrated ages are given as $1 \sigma$ age range. In case of multiple ranges, their relative probabilities (in \%) are indicated.

\begin{tabular}{llccl}
\hline $\mathrm{Nr}$ & Sample & $\begin{array}{c}\text { Lab nr } \\
(\mathrm{GrA}-)\end{array}$ & $\begin{array}{c}{ }^{14} \mathrm{C} \text { age } \\
(\mathrm{BP} \pm 1 \sigma)\end{array}$ & $\begin{array}{l}\text { Calibrated age (cal BC) } \\
1 \sigma \text { range, probability }\end{array}$ \\
\hline Ip-7 & Burial 32, charcoal & 13660 & $3850 \pm 40$ & $2405-2205$ \\
Ip-6 & Charcoal from fourth mound, paleosol 4 & 12126 & $4000 \pm 40$ & $2565-2470$ \\
Ip-8 & Burned grass under fourth mound, paleosol 3 & 13652 & $4080 \pm 40$ & $2840-2815(18 \%)$ \\
& & & & $2670-2570(67 \%)$ \\
& & 12406 & $4120 \pm 70$ & $2865-2580$ \\
Ip-9 & Burned grass from paleosol 3 & 12414 & $4100 \pm 70$ & $2860-2810(20 \%)$ \\
Ip-10 & Charcoal from third mound & & & $2750-2500(80 \%)$ \\
& & 12403 & $4150 \pm 80$ & $2875-2605$ \\
Ip-2 & Burned grass from paleosol 1 & 12402 & $4470 \pm 70$ & $3335-3030$ \\
Ip-1 & Burned grass from the upper part of first mound \\
Ip-4 & Charcoal from the upper part of first mound & 12440 & $4700 \pm 70$ & $3625-3375$ \\
Ip-12 & Hole 2, bone & 12413 & $4450 \pm 70$ & $3330-2940$ \\
Ip-13 & Hole 1, pieces of charcoal & 12412 & $4640 \pm 90$ & $3625-3340(75 \%)$ \\
& & & $3210-3140(25 \%)$ \\
\hline
\end{tabular}

Paleosol 3 yields two ${ }^{14} \mathrm{C}$ dates of burned grass that entered in the surface horizon just before the burial of the soil. The calibrated time interval is large due to a wiggle in the calibration curve. However, considering that paleosol 3 developed for about $100 \mathrm{yr}$ just before paleosol 4, its formation must have taken place in the range 2650-2550 BC.

Thus, paleosol 2 developed during the time interval 2700-2650 BC.

Paleosol 1 and the first mound of the Kurgan developed for a long period of time, based on the ${ }^{14} \mathrm{C}$ dates $4150 \pm 80 \mathrm{BP}$ and $4700 \pm 70 \mathrm{BP}$. Calibration puts the timing of this first stage of construction of the Kurgan and formation of the soil, at the interval 3500-2700 BC.

The ages of paleosols of the horizontal sequence were determined as follows. These paleosols can be classified as Solonetzs. All of them began to develop simultaneously at the beginning of the Holocene. Under the central part of the Kurgan, paleosol no. 0, part A was buried about 3500 BC, under the end of the fourth mound (paleosol no. 0, part C) at around $2550 \mathrm{BC}$, and under the fifth mound (paleosol no. 0, part C) at around 2400 BC.

\section{Paleoclimatic Reconstruction}

Paleosols of the horizontal sequence, buried under the mounds with different age of the Kurgan, were classified as Solonetz and Light Kastanozem with some Solonetzic features. They show mostly similar features, both among each other and with background Light Kastanozems with some Solonetzic features. Only the depth of the gypsum in their profiles is different because of its fast response to changes in humidity. In paleosol A, buried at $3500 \mathrm{BC}$, the depth of gypsum was $130-160 \mathrm{~cm}$; in paleosol B, buried at $2550 \mathrm{BC}$, the depth was $90-110 \mathrm{~cm}$; in paleosol C, buried at $2400 \mathrm{BC}-110$ $125 \mathrm{~cm}$, and in the background soil $160-210 \mathrm{~cm}$. The driest climatic conditions were likely to be at around $2550 \mathrm{BC}$. After $2400 \mathrm{BC}$, the climate became more humid.

The features of the paleosols in the vertical sequence suggest similar climatic changes, for the arid stages of pedogenesis in particular. Paleosol 1 developed during the interval 3500-2700 BC under climatic conditions similar to those for paleosol 0 (part A) buried under the first mound of the Kurgan. Paleosol 2 is weakly developed. There is no evidence for arid stages of pedogenesis in its soil profile, but they did occur in paleosols 3 and 4 . 
Paleosol 3 went through at least 2 stages of pedogenesis. The features of the first stage preserved in ditches where the thick humic noncalcareous horizons developed as a result of additional inflow of atmospheric water (precipitation) from the Kurgan surface. In these horizons, the humus and the carbonate $\mathrm{CO}_{2}$ contents are $1.43-1.60 \%$ and $0.01 \%$, respectively. Then, in the second arid stage of pedogenesis, in the upper part of this humic horizon, the light coloured calcareous humic Ak horizon of $5 \mathrm{~cm}$ thickness developed. The Ak horizon developed not only in ditches but also on the slopes and top of the third mound of the Kurgan as well at around 2550 BC. There is an accumulation of carbonate $\mathrm{CO}_{2}$ (to $0.53 \%$ ) and a decrease of humus (to 1.07\%) in the Ak horizon compared with the lower A horizon of the first stage of pedogenesis. On the surface of paleosol 3, the remains of burned grass were abundant. This is an obvious indication for fires. At the same time, the first desiccation cracks occurred.

Paleosol 4 went through two stages of pedogenesis as well. Unlike paleosol 3, which was buried during the second arid stage of pedogenesis, the burial of the paleosol 4 was during the second humid stage. It shows clear evidence of carbonate leaching and humus accumulation in the uppermost part of its soil profile (the carbonate $\mathrm{CO}_{2}$ content is $1.8 \%$ in $\mathrm{Ak}$ and $4.5 \%$ in $\mathrm{BCk}$; the humus content is $0.8 \%$ in $\mathrm{Ak}$ and $0.4 \%$ in $\mathrm{BCk}$ ). The desiccation cracks, up to $3 \mathrm{~m}$ deep and mainly located at the southern part of the Kurgan, coincide with the first dry stage of pedogenesis (Figure 2b). Going from a dry condition to a more humid one, slope processes become more intensive resulting in thick colluvial deposits at the bottom of the slopes of the Kurgan. Unlike paleosol 3, which was calcareous even in depressions (ditches), paleosol 4 shows evidence of more moist conditions, even on top of the Kurgan mound.

The fifth mound of the Kurgan is dated at $3850 \pm 40 \mathrm{BP}$ (Figure 2b), its calibrated age range 24002200 BC. Paleosols buried later than paleosol 4 were absent in the Kurgan, because the uppermost layers of the fifth mound have been destroyed in modern time (long before excavation). Hence, only circumstantial evidence can help to reconstruct climatic conditions of the last stage of the Kurgan construction. In the material of the fifth mound, we found evidence of considerable moistening, like clay formation.

\section{DISCUSSION AND CONCLUSION}

The stratigraphy of the large Ipatovo Kurgan provides important information on climatic change. The horizontal and vertical soil sequences show signs of abrupt periods of dry climate, and contain material suitable for ${ }^{14} \mathrm{C}$ dating. This allows us to understand soil development processes, to reconstruct climatic changes and to date them as well.

The vertical paleosol sequence from the first to the last mounds of the Kurgan is the main basis for a detailed chronology. For paleosols 1 and 3, however, this is hampered by wiggles in the calibration curve. The ages of paleosols 1 and 3 can be "corrected" using their time of duration, determined by pedological methods. The ages of paleosols in the horizontal sequence are determined using the stratigraphical correlation with soils of the vertical sequence.

The paleosols in the horizontal sequence, buried under mounds of different age, show dry climatic conditions at around $3500 \mathrm{BC}$, very dry at around $2550 \mathrm{BC}$, less dry at around $2400 \mathrm{BC}$ and most humid in modern times.

Comparison of horizontal and vertical paleosol sequences enable reconstruction of climatic changes in the dry steppe zone of the Northern Caucasus, Russia during the third millennium BC. The time interval of 3500-2600 BC, corresponding to the end of the Atlantic and to the beginning of the Sub- 
boreal period, is marked by a dry climate. The driest environments were during the second stage of paleosol 3 and the first stage of paleosol 4 development. This period can be dated at 2600-2450 BC. At 2450-2400 BC, the climate was more humid.

Indications for a strong arid climatic period during the third millennium $\mathrm{BC}$ were also found in the Don basin using palinology. It was characterized as a climatic catastrophe (Spiridonova 1991). Based on conventional ${ }^{14} \mathrm{C}$ dating, the age of this period was $3800-3900 \mathrm{BP}$ or $2200-2400 \mathrm{cal} \mathrm{BC}$.

Likewise, an arid climatic period was determined in Mesopotamia (Weiss et al. 1993). The ${ }^{14} \mathrm{C}$ age of this climatic event for both the Don and Mesopotamia regions, however, is somewhat younger than we derived for Ipatovo.

\section{REFERENCES}

Dalfes HN, Kukla G, Weiss H, editors. 1997. Third Millennium BC. Climate change and Old World collapse. Nato ASI Series. Series I: global environmental change. Vol 49. Springer Verlag.

Demkin VA. 1997. Paleopochvovedeniye i archeologiya (Paleopedology and archaeology). Pushchino: Pushchino Research Centre Press. 213 p (in Russian).

Fedoroff N, Demkin VA, Courty M-A. 1997. Non-linear behaviour of soil systems during Holocene. Mitteilungen der Osterreichischen Bodenkundlichen Gesellschaft H 55:139-43.

Gerasimenko NP. 1997. Environmental and climatic changes from 3 to $5 \mathrm{ka}$ BP in South-Eastern Ukraine. In: Dalfes HN, Kukla G, Weiss H, editors. "Third Millennium BC. Climate Change and Old World Collapse". Nato ASI Series. Series I: global environmental change. Vol 49. Springer Verlag. p 371-99.

Ivanov IV, Alexandrovskiy AL. 1987. Methods of the study of soil evolution. Soviet Soil Science 19(3):90101.

Shishov LL, Tonkonogov VD, Lebedeva II, editors. 1997. Russian soil classification. Moscow: V V
Dokuchaev Soil Science Institute Press. 236 p. ISBN 5-86921-026-7.

Spiridonova EA. 1991. Evolution of vegetation cover of the Don basin in the Upper Pleistocene-Holocene. Moscow, Nauka Press (in Russian).

Stuiver M, Reimer PJ, Bard E, Beck JW, Burr GS, Hughen KA, Kromer B, McCormac G, van der Plicht J, Spurk M. 1998. INTCAL98 radiocarbon age calibration, 24,000-0 cal BP. Radiocarbon 40(3):104183.

van der Plicht J. 1993. The Groningen Radiocarbon Calibration Program. Radiocarbon 35(3):231-7.

van der Plicht J, Wijma S, Aerts AT, Pertuisot MH, Meijer HAJ. 2000. Status report: the Groningen AMS facility. Nuclear Instruments and Methods in Physics Research B172:58-65.

Weiss H, Courty M-A, Wetterstrom W. 1993. The genesis and collapse of Third Millennium North Mesopotamian civilization. Science 261:995-1004.

[WRB] World Reference Base for Soil Resources. 1994. World soil resources reports 84.91 p. ISBN 92-5104141-5. 